patients with steroid-dependent intractabla asthma (SDIA). Relationship to clinical asthma type, and clinical efficacy. J Jpn Assoc Phys Med Baln Clim $1996 ; \mathbf{5 9}:$ 133-140

9) Tanizaki Y, Kitani H, Okazaki M, et al: Cellular composition of fluid in the airways of patients with house dust sensitive asthma, classified by clinical symptoms. Intern Med $1992 ; 31$ : 333-338

10) Tanizaki $Y$, Kitani H, Okazaki M, et al: A new modified classification of bronchial asthma based on clinical symptoms. Intern Med 1993 ; 32 : 197 203

\section{Aquabics の体力医学的検討}

東洋英和女学院大学人間科学部人間福祉学科

宮下 充正

\title{
はじめに
}

水中運動は, 競技志向の競泳, 飛込み, 水球, シンクロナイズド・スイミング，オープン・ウォ 一ター・スイミングと, 健康志向の水泳, 水中歩 (走)行, Aquabics とに大別される.

Aquabics とは, 米国で誕生した水中でのリズ ム運動で，Aerobic Dance を水の中で行うよう なものと考えてよいだろう. Aerobic Dance と 同じように軽快な音楽に合わせ，プールサイドに 立って模範演技をするインストラクターの指示に したがって行うのが普通である。

通常のプログラム時間は 40〜50 分間で，心拍 数を徐々に目標心拍数に上げ，その水準を保持 し，最後に安静状態に戻していくというように， うまく運動強度を上げ下げするような内容で構成 されている。

ここでは，水中で遂行する運動の特性と運動強 度，そして，水中で運動することを習慣化するこ とでもたらされる生理学的適応について紹介した い.

\section{水泳スピードと酸素摂取量}

水泳スピードが上がるにつれて増大する水の抵 抗に打ちかって進むためには，それに必要なエネ ルギーを消費しなければならない. 水泳スピード と水泳中の酸素摂取量との関係については, スイ ムミル（流れるプール）を利用して，Holmer が 測定，報告している3)。 それによると，酸素摂取 量は水泳スピードの上昇とほほ直線的な関係で増 加する，同じスピードで比べれば，酸素捸取量の 多いのはバ夕フライと平泳, 少ないのは背泳とク ロールである。また，レクリエーションとして泳 
いでいる人は，同じスピードで泳ぐとき，トップ レベルの水泳選手に比べ 2 3 倍多い酸素摂取量 であると報告している，水泳技術の差は，同じス ピードで泳ぐときエネルギーをいかに有効に使え るかどうか, すなわち, 酸素摂取量にはっきり現 れるというのである。

\section{水泳スピードと造波エネルギー}

泳ぐときに波が立つのは，プールの中を泳いで いる人を見ればわかる，水泳選手が引き起こす波 の高さが観察されている8).それによると，泳ぐ スピードが上がるにつれて, 波の高さから推定さ れる波のエネルギーは急増する。そして，レクリ エーションとして泳いでいる人は，同じスピード で泳ぐとき，トップレベルの水泳選手に比べ 2 3 倍多い造波エネルギーを消費しているという。 言い換えれば，水泳技術の差は，同じスピードで 泳ぐときに，いかに波を立てずに泳げるかどう か，すなわち，造波エネルギーの多い少ないには っきり現れるという。

\section{水中歩行スピードと心拍数}

水中を歩くときのエネルギー消費量は, 歩行ス ピード，歩く人の身長と水深との相対関係，体 型，プール底の形状によって異なる。水深 $1 \mathrm{~m}$
で滑りにくいタイル張りのプール（水温 $\left.30^{\circ} \mathrm{C}\right)$ を，水中歩行に慣れた 30 名の中高年齢の女性が 3 つの任意のスピード（普通に，やや速く，でき るだけ速く）で $50 \mathrm{~m}$ 歩いた直後の心拍数は, 個 人差が大きいが歩行スピードの上昇とともに約 100 拍/分から約 140 拍/分へとほほ直線的に増加 することがわかった（図 1).

\section{水中運動の特徵}

水中運動を実施するときの特性を, Maglisco と Brennan は次のようにまとめている6).

1）全身の筋肉を活動させ，特に上肢と下肢の 筋肉の持久性を発達させる。

2）水は空気よりも 1,000 倍も密度が高いので, 筋肉に強い負荷がかかり, 筋力を発達させる.

3）身体の左右の部分を等しく使うので，均整 のとれた筋肉の発達をうながす。

4）陸上でのスポーツにつきものの傷害がほと んどない.

5）体重が負担とならないので，妊婦，関節障 害からの回復過程にある人によい.

\section{水中運動の効果}

Maglisco と Brennan は，さらに，水中運動の 実践の健康に対する有益な効果を次のように 3 つ

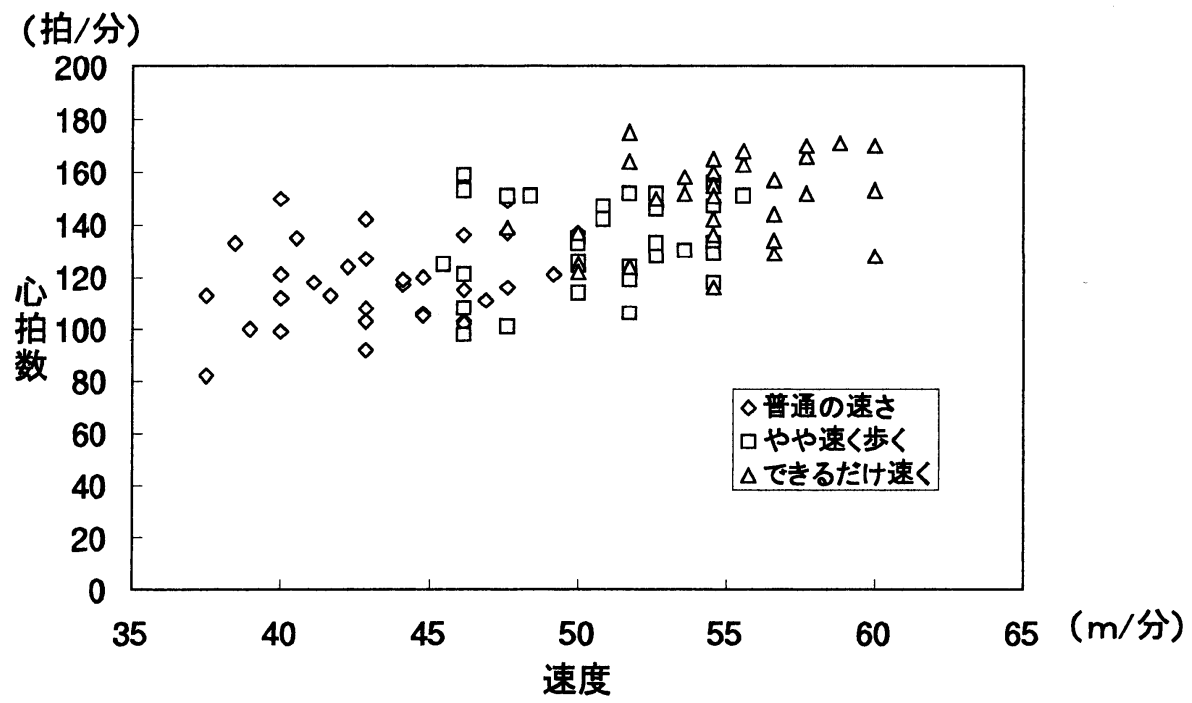

図 1 水中歩行時の速度と心拍数の関係（宮下ら，未発表資料） 
に分けて述べている ${ }^{6}$.

1）身体組成の変化：体重と体脂肪量が減少し, 筋肉量が増加する。

2）身体各部の太さの変化：腹部, 腰部, 大腿 部が細くなる.

3）循環機能の変化: 安静時心拍数, 運動時心 拍数, 血中コレステロールと中性脂肪, 血圧 が減少し, 心拍出量と HDL コレステロール が増加する。

このまとめ以降に行われた研究も, ほぼ類似の 結果を報告している。それらのうち，いくつかの 研究成果を次に報告する。

1）Aquabicsでは, テンポを上げていくと運 動強度は 2.9 から 9.2 mets , 心拍数は最高心 拍数の 45 から $75 \%$ へ増加し, これらの生理学 的反応は，トレーニング効果をもたらすのに十分 である (Cassadyと Nielsen) ${ }^{2)}$.

2）水中を主観的にゆっくり歩くからできるだ け速く歩くと, 酸素摄取量は 0.5 加 $0.8 \mathrm{l} /$ 分 へ, 心拍数は 70 から 90 拍/分へと増加し, これ らの值からみると，高齢者に適した運動である $(\mathrm{Yu} ら)^{11)}$.

3）ベストをつけての水中走行は，同じ努力で 陸上のトレッドミル上を走るときの $64 \%$ となる (Bishop ら $)^{1)}$. あるいは, $1.3 \mathrm{~m}$ の水深で走行す るときは，90.3\%となる (Town と Bradley) ${ }^{9)}$.

4）妊婦が水中で運動するときは, 陸上で運動 するときに比べ胎児の心拍数の上昇が少ないこ と, そして妊婦自身の心拍数が少なく血圧が低い ことから, 水中運動は妊娠中の女性に適している $(\text { Katz })^{4)}$.

5）リウマチ性関節症の人は, ベストをつけて 水中走行するのは気分がよく，しかも十分な運動 効果が得られる (Melton-Rogers ら ${ }^{7)}$.

6) マスターズスイマーの最大酸素摂取量は同 年代の一般人に比べて大きい (甲田ら $)^{5)}$.

7）閉経後の女性に対して，水中運動は骨密度 の減少傾向をゆるめるのに効果的であり, 活動的 な日常生活を送る習慣を身につけるのに役立つ (Tsukahara ら $)^{10)}$.

\section{むすび}

健康志向型水中運動の指導の歴史は浅く, 研究 も十分に行われていないが，高齢社会を迎えて中 高年者に安全で, しかも, 効果のある水中運動の 指導法を確立することは急務であろう。また，そ のような人たちが，いつでも利用できる水中運動 用の施設の建設が望まれるところである.

\section{文献}

1) Bishop PA, et al: Physiologic responses to treadmill and water running. Phys Sportsmed $1981 ; 17$ : $87-94$

2) Cassady SL, Nielsen DH : Cardiorespiratory responses of healthy subjects to calisthenics per formed on land versus in water. Thys Ther 1992 ; $72: 532-538$

3) Holmer I: Physiology of swimming man. Acta Physiol Scand 1974 ; Suppl 407

4) Katz VL: Water exercise in pregnancy. Semin Perinatol 1996; 20 : 285-291

5) Koda M, et al: Physical and physiological characteristics in middle-aged and aged swimmers. in Physical Activity, Aging and Sports (eds by Harris $\mathrm{S}$, et al). Vol III: Toward Healthy AgingInternational Perspectives. Part I. Physiological and Biomedical Aspects. Center for the Study of Aging, 1994 ; pp 41-47

6) Maglisco S, Brennan M : Swim for the Health of It. Mayfield Publ Co, 1985

7) Melton-Rogers S, et al: Cardiorespiratory responses of patients with rheumatoid arthritis during bicycle riding and running in water. Phys Ther $1996 ; 76: 1058-1065$

8) Takamoto $M$, et al: Wave height in relation to swimming velocity and proficiency in front crawl. in Biomechanics IX B, Human Kinetics (eds by Winter PA, et al). 1983 ; pp 486-491

9) Town GP, Bradley SS : Maximal metabolic responses of deep and shallow water running in trained runners. Med Sci Sport Exerc 1991; 23: 238-241

10) Tsukahara N, et al: Cross-sectional and longitudinal studies on effect of water exercise in controlling bone loss in Japanese postmenopausal women. J Nutr Sci Vitaminol $1994 ; 4$ : 37-47

11) $\mathrm{Yu} \mathrm{E}$, et al : Cardiorespiratory responses to walking in water. in Medicine and Science in Aquatic Sports (eds by Miyashita M, et al). Konger Basel ; Med Sport Sci $1994 ; 39$ : 35-41 